
МЕНТАЛИТЕТА И МЕТОДОЛОГИЯ ЕГО ИЗУЧЕНИЯ

\title{
С.В. Чугров
}

Высокая степень и возрастающая интенсивность глобализации современного мира несомненны. Напряженный диалог цивилизаций (нередко сопровождающийся культурными интервенциями) порой превращается в их столкновение. Многие нации склоняются к заимствованию стандартных норм и унификации ценностных систем. Как отмечает, например, исследователь цивилизационных процессов А.Неклесса, в социальном универсуме под влиянием массовой культуры и иных феноменов массового общества "модель поведения большей части человечества заметно унифицируется, уполощается и подчиняется стереотипам, объединяя субъекта с исполняемой им социальной функцией (ролью)” [Неклесса 2002: 9].

Вместе с тем в качестве реакции на глобализацию нарастают разнообразие и фрагментированность (так наз. глокализация) современного мира [Лебедева, Мельвиль 1999: 76]. Проблемное пространство общества определяется стремительным возрастанием сложности, открытости и неустойчивости социума, что и предопределяет принципиально новый нелинейный характер динамики взаимоотношений социальных индивидов и общностей [Кравченко, Романов 2004: 3]. Инновационный тип развития в условиях глобализации требует максимального раскрытия специфического творческого потенциала индивида и нации. В то же время в современном мире политика агрессивного отторжения чужих ценностей, стремление отгородиться от “иностранного влияния" создает реальную опасность самоизоляции.

В связи с этим можно предложить типологию наций, исходящую из принципа адаптивности к инокультурному влиянию и разделяющую их на 1) исповедующие непреклонность в борьбе с “засильем инородных ценностей" (например, Иран); 2) заимствующие всецело и безо всякого сопротивления чужие аксиологические системы (саму их суть, а не только внешние атрибуты) и утрачивающие свою сущностную ценностную систему (например, Пуэрто-Рико, территория, ассоциированная с США); и 3) органично впитывающие все полезное из зарубежного опыта, но вместе с тем, сохраняющие наиболее глубинные черты своей идентичности (например, Япония).

Чтобы с максимальной полнотой охарактеризовать в данной статье упомянутые тенденции, мы попытаемся обосновать необходимость введения нового понятия “внешнеполитического менталитета", относительно строгое определение которого мы сможем дать позднее, по завершении необходимого для этого предваряющего изложения. Пока же мы ограничимся его использованием в качестве рабочего (ad hoc), операционального термина, пригодного, на наш взгляд, для анализа причин зарождения этнических противоречий и конфликтов, а также для понимания специфики восприятия окружающего мира представителями той или иной нации.

ЧУГРОВ Сергей Владиславович, профессор МГИМО(У) МИД РФ. 


\section{К ОБЩЕЙ ХАРАКТЕРИСТИКЕ ПОНЯТИЯ “МЕНТАЛИТЕТ"}

Более широкое относительно вводимого нами понятие "менталитет" является вполне устоявшимся в этнологии, антропологии и истории, и кроме того претендует на прочное место в категориальной системе политологии и социологии международных отношений и межэтнических конфликтов [Чернышева 2003: 14-20].

Менталитет - весьма сложное, многогранное проявление психической деятельности социальных индивидов изоморфического типа. Оно включает специфическое соотношение (как сознательное, так и бессознательное) между рациональным и эмоциональным в их действиях, а также между особенностями мышления национально-этнической группы и общности в целом, между стремлениями к инновациям и к сохранению культурного потенциала прошлого. Естественно, что такое комплексное явление представлено широким спектром научных исследований, проанализированных нами прежде всего с точки зрения их методологической значимости и, разумеется, исторического контекста (что-то выдержало испытание временем, а что-то - нет).

Объектом исследования этнонационального менталитета, как правило, являются особенности социокультурной идентичности нации, изменения, происходящие в глубинных пластах массового сознания и коллективного бессознательного в периоды радикальных общественных трансформаций. При этом особый интерес представляет исследование динамики воздействия различных факторов (например, социокультурной традиции) на менталитет, выступающий в роли важного элемента идентификационной матрицы нации.

Выбор теоретико-методологического инструментария обычно обусловлен как сложной природой менталитета, так и особым интересом к политическому мировосприятию, в концентрированном виде выражающему себя во внешнеполитическом менталитете и, наконец, необходимостью проанализировать взаимообусловленность внешнеполитического менталитета и характера коммуникаций. При этом, соответственно, важное методологическое значение приобретают:

- теория коммуникативного действия Ю.Хабермаса, дающая инструментарий исследования особенностей современных коммуникаций;

- теории транзитологии и конфликта цивилизаций (С.Хантингтона) применительно к исследованию динамики самоидентификаций людей в обществах переходного типа;

- теоретико-методологический инструментарий исследования этнической составляющей менталитета, получивший обоснование в трудах многочисленных российских ученых (Ю.В.Арутюняна, Л.М.Дробижевой, Б.С.Ерасова, Г.В.Осипова, В.А.Тишкова и др.).

- методология исследования ментальных и социокультурных конфликтов, разрабатываемая в трудах отечественных и зарубежных ученых [см., например, Горшков 2003; Тощенко 2003; Штомпка 1996].

Основными методами исследования ментальностей являются классификация научных данных, их типологизация, общефилософский, культурно-компаративистский и историко-проблемный анализ. Также в качестве экспликативных приемов социологического исследования полезно опираться на анализ динамики результатов опросов общественного мнения. 
В литературе практически нет фундаментальных работ, посвященных осмыслению внешнеполитических реалий в массовом сознании, а также роли архетипов, стереотипов, мифов, которые ориентированы на “Они”группы. Картина характера внешнеполитических коммуникаций становится гораздо богаче смысловыми оттенками, если в анализ включен фактор менталитета. Исследование характера коммуникаций в контексте того, кем люди себя ощущают и как они воспринимают инициированные извне радикальные трансформации, дадут новый импульс изучения глобальных и глоболокальных преобразований.

\section{ИЗ ИСТОРИИ ИЗУЧЕНИЯ МЕНТАЛИТЕТА}

Понятие "менталитет” зародилось во Франции и чуть позднее - в Германии. В трудах Ш.Монтескье, Ж.-Б.Вико, И.Гердера, Г.Гегеля и других мыслителей уже присутствовала концепция "народного духа" определенных наций. В общем виде понятие коллективного менталитета можно найти в работе А. де Токвиля “Демократия в Америке” (1835 г.). Именно Токвиль, стремясь обозначить первопричины национальной специфики, сфокусировал внимание на общем происхождении предрассудков, стереотипов и пристрастий, господствовавших в среде американцев. Исследуя сходные принципы мышления жителей Соединенных Штатов, он стал прародителем психоистории и изысканий в области менталитета и стереотипизации мышления. В 1856 г. американский ученый Р.Эмерсон впервые целенаправленно использовал “менталитет” как термин для анализа метафизического значения души как первоисточника ценностей и истин.

В 1859 г. М.Лацарус и Х.Штейнталь провозгласили новое направление в социальной науке - этническую психологию. Эти идеи впоследствии разрабатывали В.Вундт, Г.Шпет, Г.Лебон, Р.Тард и др. [см. Рогальская 2006: 1]. В психологию термин "менталитет" был введен Ш.Блонделем в 1926 г., а более основательно А.Валлоном в 1928 г., хотя нельзя сказать, что в то время он был принят всеми психологами. Затем его подхватили неокантианцы и феноменологи. Особенно тщательно понятие изучалось французскими социальными науками в начале XX в. В эссеистской литературе его широко использовал М.Пруст.

Научная разработка концепций менталитета велась на стыке исследований сознательного и бессознательного. В работах обществоведов-классиков конца XIX - начала XX вв., таких как Э.Дюркгейм, К.Маркс, М.Вебер, проблематика сознания рассматривалась в контексте вычленения его социокультурной обусловленности, раскрытия различных уровней (в частности, были выделены индивидуальное, групповое, классовое сознание) [см. Дюркгейм 2006; Маркс 2000; Вебер 1994]. В эволюционизме, а затем социологическом рационализме Дюркгейма разрабатывалась концепция примитивного менталитета, отнесенного к архаическому этапу развития человеческого социума [Дюркгейм 1996]. В своих работах ученый пришел к выводу, что ментальные состояния общества есть не что иное, как коллективные представления. Развитие концепции менталитета проходило в русле представлений о том, что общественное сознание существует в неразрывной связи с коллективным бессознательным, и в реальных действиях людей всегда соотносятся функции интеллекта и эмоций. 
Неоценимый вклад в разработку понятия “менталитет” в антропологии и этнологии внес Л.Леви-Брюль. В своих работах "Ментальные функции в низших обществах" и "Первобытный менталитет" он проанализировал дологическое мышление и отметил сущностные отличия примитивной ментальности от цивилизованной, не исключая, что могут быть и переходные состояния. Примитивный менталитет (богов, демонов и пр.) он описывал с помощью введенного им понятия “аффективная категория сверхъестественного”, позволяющего понять, как примитивный человек воспринимает магию, сны, видения и мистический опыт иного рода. Это направление дало толчок исследованиям архетипов, оказывающих серьезное влияние на формирование менталитета современных сообществ, особенно сохраняющих сильные элементы традиционализма. Благодаря изысканиям Леви-Брюля структура менталитета предстает как логически организованная и рациональная [см. Ментальность, менталитет б.г.].

Важное значение для исследования менталитета имели работы французских философов-структуралистов (М.Фуко, К.Леви-Стросс), а также социальный и гуманистический психоанализ З.Фрейда, К.Юнга, К.Хорни, Н.Смелсера и др. Научные откровения в работах Фрейда и его последователей [см., например, Фрейд 1991; Лебон 1995] позволили свести в одну систему индивидуальную и коллективную психологию (обосновывая переход к изучению коллективной психологии, Фрейд обратился сначала к “архаическому наследию”, влияющему на формирование личности). Это лишний раз доказывает, что в любом конкретном исследовании современного менталитета необходимо обращение к более ранним эпохам*.

Сталинизм и фашизм, выразившиеся в массовом проявлении деструктивности, вызвали к жизни новое направление исследований ментальности. Феноменологи, представители социологии знания и Франкфуртской школы подвергли критическому анализу утверждения, согласно которым социальные факты и общественное бытие всецело определяют характер сознания. Э.Фромм не только изучал особенности социальных и национальных характеров, но и пытался проследить их воздействие на здоровье/болезнь общества [Фромм 2004].

Отметим вклад в исследование менталитета Т.Адорно [Адорно 2001] и его коллег, раскрывших механизмы манипулятивного воздействия на сознание людей), М.Хоркхаймера, Г.Маркузе, выявивших корреляции между особым мировосприятием и характерными политическими действиями [Маркузе 2003], А.Шюца, показавшего активную роль сознания, которое далеко не всегда, как ранее полагали, отстает от общественного бытия [Шюц 2004], П.Бергера и Т.Лукмана, обосновавших теорию, согласно которой сознание конструирует социальную реальность [Бергер, Лукман 1995], К.Манхейма, который одним из первых глубоко и всесторонне исследовал политическое сознание как одну из важнейших форм сознания общественного [Манхейм 1994]. Интересны и некоторые современные социологические интерпретации сознания, содержащиеся в работах российских ученых

\footnotetext{
* В России данной проблематикой занимался Н.Михайловский, создавший теорию социального подражания [Михайловский 1998].
} 
[см., например, Грушин 1987; Кола 2001; Михайлов 1990; Попов 1997; Степин 2000]. Проблемы общественной и национальной психологии, их влияние на демократию выразительно раскрыты в работах видного российского исследователя Г.Дилигенского [см., например, Дилигенский 1998].

C начала XX в. слово “менталитет” вошло в повседневный лексикон европейских народов и применялось как модное mot, обозначавшее преимущественно мироощущение и поведение масс, "формы духа", которые вполне адекватно передаются также немецким словом "Weltanschauung". Параллельно термин "менталитет" прочно вошел в научный оборот с несколькими различающимися оттенками смысла [Рогальская 2006].

Теоретики французской школы “Анналов” рассматривали менталитет как “стержень” истории, одну из истинно “движущих сил” культуры, своего рода “иного плана” реальность, хранящую “потаенный” слой неясных образов, стереотипов восприятия и ценностных ориентаций, скрытых за "внешним миром" идеологических конструктов [см. Южалина 2002]. М.Блок понимал под менталитетом (ментальностью) “групповое, коллективное сознание" [Блок 1993]. Особенно глубокую интерпретацию понятия дал Ле Февр, - один из основателей, наряду с М.Блоком, школы “Анналов” - определявший менталитет как “преломление коллективного в индивидуальном” [Февр 1991]. Он указал на сочетание в коллективном менталитете не только биологических и психологических, но и социальных детерминант. Новое поколение школы “Анналов” - Ж.Ле Гофф, Ж.Дюби, Р.Мандру и др. - сосредоточило усилия на моделировании менталитета разных культурных эпох.

Российская наука еще с начала XIX в. синонимично использовала такие понятия, как “душа народа”, “национальный характер”, “национальное сознание” и т.п. На наш взгляд, вполне удачны и интересны были попытки разработки социально-политических и философских концепций национального характера К.Бэра, К.Кавелина, Н.Надеждина. Высшие достижения российской духовной культуры, теснейшим образом связанные с изучением "народной души" и взаимообусловленности глубинных проявлений коллективного сознательного и бессознательного, можно обнаружить в произведениях виднейших религиозных философов конца XIX - начала XX вв. В.Зеньковского, Л.Карсавина, В.Соловьева, Г.Федотова и др. Научным изучением этой проблемы активно занимались Н.Лосский [Лосский 2000], В.Ключевский [Ключевский 1987], И.Ильин [Ильин 1993], Н.Бердяев [Бердяев 2004]. И хотя авторы предпочитали называть предмет своего анализа "народным духом", его безо всякого ущерба для смысла можно было бы заменить более современным словом “менталитет”, учитывая, что дух выражается через дискурс, вербальные и невербальные памятники культуры нации [Рогальская 2006]. Особо следует отметить вклад в разработку данной проблематики П.Сорокина, пытавшегося проследить влияние социальной и культурной динамики на типы мышления и поведения людей в разных культурах [Сорокин 2006].

В советское время исследования менталитета находились под запретом, так как вступали в противоречие с идеологическими догматами о всесилии человеческого разума. С конца 1980-х годов страна стала открытой для реального международного сотрудничества ученых, что сделало возможным открытые 
исследования сферы бессознательного [см., например, Ахиезер 1998; Бутенко, Колесниченко 1996; Мнацаканян 2005; Мостовая, Скорик 1995; Панарин 2002; Таршис 1999; Федотова 1997]. Начиная с 1990-х годов, “менталитет” становится одним из наиболее часто употребляемых терминов в исследованиях современных российских социологов, культурологов и политологов. Тем не менее, на наш взгляд, было бы несколько преждевременным утверждать, что этот термин уже окончательно прижился в российской науке.

\section{МЕНТАЛИТЕТ КАК КАТЕГОРИЯ ОБЩЕСТВЕННОЙ НАУКИ}

Отсутствие однозначного определения термина "менталитет” изначально заложено в его семантической многозначности, восходящей к латинскому mentis (ум, мышление, умонастроение и т.д.). В англоязычных словарях mentality обычно - склад ума, умонастроение, умственное развитие, “образ мыслей, направление или характер размышлений” [Webster's... 1961: 1411], "сумма мыслительных способностей или возможностей, отличающихся от физических” [Funk \& Wagnalis 1962: 1552], “обобщение всех характеристик, отличающих ум” [Drever 1967: 171], “установки, настроение, содержание ума" [The Universal... 1957: 720], “способность или сила разума" [Chaplin 1975: 313]. Достоинство этих дефиниций состоит в их лаконичности. Взятые вместе, они представляют достаточно адекватную трактовку термина, однако ни одна из них в отдельности не отражает многогранности явления. В немецких словарях Mentalität определяется как образ мыслей, мышление. Во французских словниках mentalité - направленность мыслей, склад ума и т.д.

Определения “менталитета" в российских энциклопедических словарях также грешат некоторой неполнотой: “определенный образ мыслей, совокупность умственных навыков и духовных установок, присущих отдельному человеку или общественной группе” (Энциклопедический словарь “Терра Лексикон” [Новиков (ред.) 1998: 349]), “менталитет (франц. mentalité, от позднелат. Mentalis - умственный), образ мышления, мировосприятия, духовной настроенности, присущие индивиду или группе... В российской философии, культурологии и публицистике обычно употребляется для характеристики национальных особенностей народов, особенностей культуры. Например, черты русского М. - духовность, коллективизм (соборность), широта души" (Словарь по культурологии [Кравченко 2000: 343-344]), “образ мышления, общая духовная настроенность человека или группы” (Философский энциклопедический словарь [Губский (ред.) 2002: 263]).

Р.Манекин трактует менталитет как "совокупность представлений, воззрений, 'чувствований' общности людей определенной эпохи, географической области и социальной среды, особый психологический уклад общества, влияющий на исторические и социальные процессы” [Манекин 1991: 28-33]. Отметим, что слово “чувствования” социолог заключает в кавычки, что свидетельствует о некоторой неуверенности в научной строгости толкования термина, несущей ущерб семантике дефиниции. Такое определение едва ли можно считать исчерпывающим, так как оно, по сути, тождественно определению массового сознания. Если бы такое тождество имело место, исчез бы всякий смысл утяжелять тезаурус понятием “менталитет”. Но в вышеприведенном определении исчезла именно специфика этого 
понятия - отражать внешний мир, определяя особенности способов реагирования больших человеческих общностей.

Весьма лаконичное, с академической точки зрения, определение дает Э.Тадевосян: “...устойчивый, общераспространенный в той или иной группе людей особый мыслительный образ (обобщение, представление) о какомлибо лице, социальной группе, социальном институте или организации" [Кравченко (ред.) 1997: 78]. Эта дефиниция привлекает своей простотой, понятностью, однако сведение понятия менталитет лишь к “мыслительному образу" представляется нам слишком узким. Скорее, “менталитет” - это совокупность, более того, система образов, обобщений и представлений. Не менее узок и объект представления "о каком-то лице, социальной группе, социальном институте или организации”. В расширительном плане более целесообразно применять в исследовании объект в виде, скажем, “определенного социального или политического устройства”. Справедливо рассматривать менталитет еще шире - как системно-структурное мировидение в облике образов мира. В различных областях знаний менталитет предстает как “совокупность умственных привычек, верований, психологических установок, характерных для какой-либо общности людей или группы”, “состояние ума", “совокупность манер поведения, мышления, суждения о чем-либо”, моральных установок [Южалина 2002: 7].

Приведем еще одно из достаточно поздних и потому зрелых определений: “Ментальность, менталитет (от лат. - ум, мышление, образ мыслей, душевный склад) - общая духовная настроенность, относительно целостная совокупность мыслей, верований, навыков духа, которая создает картину мина и скрепляет единство культурной традиции или какого-либо сообщества... Таким образом, менталитет, по нашему мнению, - сложная многоуровневая система образов и представлений, архетипов сознания, обнаруживающихся в видах жизнедеятельности личности, социумов и детерминируемых этноестественно-историческими процессами” [Душков 2002: 2-3, 16].

По мнению О.Корнилова, разрабатывающего теорию двукодового характера репрезентации реальности в человеческом сознании, вектор детерминированности национального менталитета определяется следующим образом: на этапе складывания этноса и его языка внешняя среда обитания (климат, рельеф, растительность и другие факторы) формирует генотип народа, включающий существенные черты национального характера и менталитета. Эти черты запечатлеваются в матрицах национального языка, прежде всего, в лексике. На более поздних этапах развития социума роль внешней среды уменьшается или даже полностью сходит на нет, и язык превращается в основной фактор преемственности национальных особенностей характера и менталитета, играющий роль своего рода “когнитивноэтнической вакцины”, с помощью которой сформированные ранее национально-специфические черты ментальности и характера “прививаются" более поздним поколениям [Корнилов 2000].

Многозначность трактовки понятия “менталитет”, входящего в инструментарий сразу нескольких отраслей знания, создает определенные сложности при его применении. Так, этнопсихология, в которой “менталитет" конституирован, пожалуй, прочнее всего, анализирует психологические 
черты наций и этносов. Специфика национального мышления представляет собой инструмент этнической компаративистики. Этнолингвистика проводит исследования взаимоотношений этнической культуры и языка. Этносоциология проводит сравнительный анализ социальных институтов, а также социальных проблем жизнедеятельности этносов. Социальный историк видит в менталитете обобщенный способ восприятия мира, манеру чувствовать, характерную для людей определенной эпохи. Социальный психолог связывает с менталитетом взаимообусловленные психологические реакции, представления и качества, несущие в себе остатки опыта предыдущих поколений, “самопонимание групп” (Ю.Митке). Для исследователя, изучающего влияние СМИ на массовое сознание, особенно важна роль социолингвистики, которая выявляет в менталитете семантическую матрицу, предопределяющую смысловые реакции культурных субъектов; при этом совокупность концептов языка образует языковую картину мира, а совокупность прототипов этих концептов - национальный образ мира. С точки зрения политической культуры, как считают специалисты, менталитет - это совокупность компонентов политического и социокультурного опыта личности или общности (народов, прослоек общества, сект и т.д.). Кроме того, весьма важно, что внешнеполитический менталитет обусловливает способность нации воспринимать свое окружение в определенном свете, отдавать предпочтение тем или иным ценностям, нормам, стереотипам и т.д.

Таким образом, принадлежность термина "менталитет” тезаурусу различных гуманитарных дисциплин, его диффузная природа, некоторая расплывчатость и незавершенность делают понятными довольно позднее вхождение его в инструментарий общественных наук, трудности в исследовании, слабую методологическую обоснованность.

\section{МЕНТАЛИТЕТ И МЕНТАЛЬНОСТЬ}

Хотя проблемы разграничения между терминами “менталитет" и “ментальность” в большинстве европейских языков не существует (поскольку термин mentality, mentalitŭ, Mentalitวt и т.д. инвариантен), в отечественных исследованиях введение “водораздела" между ними представляется необходимым [см., например, Вальцев 2004]. Примеры обратного [Ментальность, менталитет б.г.] показывают, что смешение этих понятий, пусть даже очень близких, не оказывается не вполне корректным. Дело в том, что термин “ментальность” образован от прилагательного “ментальный”, производного от термина "менталитет". Тем самым намечается коллизия между терминами "менталитет" и “ментальность". Л.Пушкарев [там же], воспринимающий грамматическую преемственность несколько по-иному, указывает на то, что с помощью суффикса “-ность” от основ имен прилагательных образуются, как правило, существительные, обозначающие признак, отвлеченный от предмета, а также качество или состояние. По этой причине, считает исследователь, “ментальность" следует рассматривать как признак мыслящего человека (совокупности людей), характерный для данного лица или коллектива в конкретное время; иными словами, "менталитет” имеет общечеловеческое значение, в то время как “ментальность” можно отнести к различным социальным стратам и историческим периодам. 
О.Усенко, одним из первых попытавшийся обосновать различие между рассматриваемыми терминами, рекомендовал понимать под "ментальностью” “универсальную способность индивидуальной психики хранить в себе типические инвариантные структуры, в которых проявляется принадлежность индивида к определенному социуму и времени” [Усенко 1994: 15]. Как отмечает В.Козловский, оба явления связаны с особенностями индивидуального и группового мышления, которое может быть охарактеризовано такими специфическими, хотя и близкими, чертами, как набор свойств, качеств, особый тип, способ мыслительной деятельности. Ментальность, по его мнению, “не является психическим состоянием, а представляет собой социокультурный феномен”. Менталитет же “выражает упорядоченность ментальности и определяет стереотипное отношение к окружающему миру, обеспечивает возможность адаптации к внешним условиям и корректирует выбор альтернатив социального поведения" [Козловский 1997: 19].

Ментальность нередко рассматривается философами и социологами в значении личностной либо социальной памяти человека (социума), свойственной только ему, как “способность психики индивида хранить в себе те или иные данные, структуры, характеристики и т.д., обуславливающие его принадлежность к определенному социуму или историческому времени”. Смысловое сближение "ментальности" и “менталитета", считает Н.Южалина, стало возможным благодаря истолкованию первой категории в качестве специфического содержания индивидуальной памяти, характеризующего через индивида тот социальный круг, слой, сословие, народ, к которым принадлежит личность [Южалина 2002: 10].

Отметим еще один аспект: менталитет, в отличие от ментальности, имеет более ярко выраженный теоретический компонент. В обыденной жизни, как правило, приходится иметь дело с ментальностью, под которой понимают частичное, аспектное проявление менталитета, хотя для теоретического анализа важнее менталитет [Ануфриев, Лесная 1997]. Иными словами, менталитет фиксирует содержательные стороны опыта социума, тогда как ментальность относится скорее к функционально-динамическому аспекту опыта социума или индивида. К тому же субъектом менталитета является скорее не индивид, а социум. Тем не менее в целом различие между менталитетом и ментальностью не представляется нам принципиальным, несмотря на отмеченные нюансы. В политических и социологических исследованиях в большинстве случаев эти термины могут, с определенными оговорками, употребляться синонимично, в отличие от понятий внешнеполитического сознания и внешнеполитического менталитета, где отличие оказывается весьма существенным.

\section{СОЗНАНИЕ И МЕНТАЛИТЕТ}

Вопрос о соотношении сознания и менталитета - один из центральных для обоснования выделения внешнеполитического менталитета в отдельную категорию. Суть в том, что в менталитете присутствуют как сознательные, так и бессознательные элементы. Можно ли в этом контексте приравнять его к теоретическим формам общественного сознания? Социальное поведение отнюдь не состоит из непрестанной аналитической деятельности. Интерпретация того или иного явления и вообее восприятие мира в 
существенной степени формируются в глубинах подсознания. Если доктрины и идеологические конструкты представляют собой продуманные и законченные системы, то ключевые качества менталитета принципиально иные - открытость, незавершенность, континуальность, диффузная природа, “разлитость” в культуре и обыденном сознании. Таким образом, понятие "менталитет” позволяет соединить развитые формы сознания с полуосознанными культурными шифрами [Пушкарев, Пушкарева б.г.].

Подобное сходство/различие есть и между менталитетом и мировоззрением. Последнее представляет собой определенный, “особый вид идеологии, в соответствии с которым осуществляется систематизация образа мира, человека, общества, а также дается ответ на вопрос о смысле жизни и о моральном долге человека” [Вятр 1979: 403]. В этом определении мы хотели обратить внимание на выделенную курсивом формулировку.

Менталитет не может быть всецело осознан и сформулирован самим носителем, коль скоро он подчас выступает в роли неосознанных впечатлений, представлений, ощущений, на основе которых формируется образ окружающего мира. Подчеркнем, менталитет не тождественен сознанию, он нередко диссонирует с высказываемыми мыслями и представляет собой своего рода фон. Иначе говоря, менталитет - это далеко не всегда четкие и вербализированные установки сознания, которые включают базовые представления индивидуума или группы о себе и своем месте в обществе; он основывается не на системе логических категорий, а на противоречивых, “вживленных" стереотипах, представлениях, которые располагают индивидуума или группу к определенным типам реакций. Менталитет диктует характер и формы поведения индивидуума в рамках той или иной общности. Будучи “фундаментом мировосприятия, вместилищем дологических, изначальных форм опыта, менталитет определяет содержание интеллектуального ‘багажа’ индивидуума или группы” [Южалина 2002: 6-7].

Важно также провести различия между менталитетом, с одной стороны, и идеологией, общественными настроениями, с другой. Общественные настроения часто основываются на полуосознанных социокультурных шифрах, они неустойчивы, склонны к переменам. Более устойчивый и прочный менталитет в большей мере близок к константам; он включает в себя, в частности, и ценностные ориентации, отражающие жизненные установки, самостоятельный выбор предпочтений. Ценности познаваемы, менталитет же восходит к бессознательным глубинам психики.

Иногда понятие "менталитет" используют как синоним системы ценностей общества. Однако ценностная система значительно более гибка и пластична, а менталитет, несмотря на способность к неторопливым, постепенным трансформациям, - долгоживущий феномен, который можно считать константой. Менталитет определяет не ценности, а правила выработки ценностных суждений; он не тождественен общественному сознанию, а характеризует лишь специфику этого сознания относительно общественного сознания других групп людей. При этом речь идет, как правило, о таких больших группах, как этнос, нация или, по крайней мере, социальный слой [Боткин 1986: 114-115].

Весьма существенно и то, что основной структурной единицей, базисным трансперсональным элементом менталитета ряд исследователей 
[см., напр. Дилигенский 1999] считают архетип. Изначально архетипы, общие для всего человечества (хаос, укрощенный огонь, оружие, мужское и жкенское начала и т.д.), внедрены в менталитет в качестве констант опыта нации. В целом же, менталитет нации отмечен печатью мифологической апперцепции, поскольку в своем развитии с момента рождения до периода зрелости она проходит те же фазы, которые на протяжении тысячелетий проходило человечество. Архетипы лежат в основе определенных участков политического сознания, а мифологизация фактов обыденной жизни одинакова и для древнего, и для современного человека. Однако во втором случае под влиянием различного рода внутренних запретов мифологемы оттесняются в подсознание, образуя архетип, который среди других качеств содержит нечто личное, смутное, наивное. Проекция архетипа в сознание в политическом контексте образует политический миф - ключевой смысложизненный элемент менталитета.

\section{ВНЕШНЕПОЛИТИЧЕСКИЙ МЕНТАЛИТЕТ: СМЕНА ОРИЕНТИРОВ ПОД ВЛИЯНИЕМ ГЛОБАЛИЗАЦИИ}

Внешнеполитические аспекты менталитета как правило описываются с помощью словосочетания "внешнеполитическое сознание”, которое употребляется в научной литературе окказионально, например: “Политическое (надо добавить, и внешнеполитическое) сознание в обществе соотносится с политическими отношениями: внутренними и международными” [Егорова 1988: 10]. Вводя и обосновывая особое понятие внешнеполитического менталитета, попробуем теперь дать его относительно строгое определение.

Внешнеполитический менталитет - это та часть глубинного коллективного самосознания и самоощущения членов общества, которая включает в себя свойственное им коллективное бессознательное в виде специфических архетипов и врожденных образов и выражается в особом политическом мировосприятии, основанном на долгоживущих, устойчивых самоидентификациях по отношению к иным социокультурным и национально-этническим группам; это часть самосознания и самоощущения общества, которая относится к проблематике международных отношений $и$, в частности, $к$ политической самоидентификации по отношению к окружающему миру.

Понятие внешнеполитический менталитет ранее не использовалось в качестве инструмента научного исследования. По существу, оно предполагает обоснование нового подхода к изучению общего склада политического сознания и его динамики, особенно в периоды социальных трансформаций. Мы не абсолютизируем его эвристические возможности и не противопоставляем другим категориям. Вместе с тем, этот феномен не просто отражает спонтанную реакцию общественного мнения на те или иные внешнеполитические пертурбации, но представляет собой ожидаемые, предсказуемые реакции, поскольку основан на достаточно устойчивом комплексе представлений, знаний, стереотипов.

В определенном контексте вполне возможно противопоставление внешнеполитического менталитета внутриполитическому, под которым мы понимаем комплекс представлений, знаний, стереотипов, отражающих отношение нации к своему внутреннему устроению, функционированию 
институтов власти, важнейшим социальным проблемам и т.д. Предметом изучения в этом случае, подчеркивает С.Медведева, могут быть “стереотипы политиков и стереотипы о политиках, стереотипы, навязываемые населению политическими партиями, и стереотипные образы самих партий, распространенные в массовом сознании...” [Медведева 2006: 7].

Внешнеполитический менталитет не менее важен, нежели внутриполитический, поскольку позиционирование нации по отношению к внешнему миру имеет решающее значение для ее самоидентификации и формирования системы ценностных ориентаций, т.е. для основ национального бытия. Объединяя в себе чувственное, подсознательное отношение людей к определенным элементам мироустройства, он помогает осознать своеобразие восприятия и оценки нацией внешнеполитических процессов, оказывается необходимым для обеспечения ее единства и ощущения ею своей целостности на основе общих ценностей, норм и стандартов поведения, стереотипов сознания. В конечном счете, он помогает выстроить национальную идентичность, опираясь на противопоставление “Мы - Они”. А.Шюц делает акцент на дуальности понятий “свой/чужой”, подразумевая возникновение некоего связующего звена между ними, не способными существовать одно без другого [Шюц 2004].

Внешнеполитический менталитет можно рассматривать применительно к нации в целом, но все же более корректно будет анализировать его отдельно для политического класса, академического сообщества и народных масс, принимая во внимание "сложное соотношение культуры сneциалистов и культуры повседневной жмизни” [Хабермас 2003: 351]. Естественно, в национальном внешнеполитическом менталитете нет единого структурированного образа внешнего мира. В реальности есть переплетение образов, различные блоки и пласты внешнеполитических стереотипов и ориентаций, которые причудливо сочетаются в сознании человека, накладываясь друг на друга.

Внешнеполитический менталитет обладает отчетливо выраженной инертностью, изменяется крайне сложно и в течение длительного времени. Он состоит из константных и изменчивых элементов. Константы, доминирующие во внешнеполитическом менталитете, - это элементы, восходящие к архетипам и представляющие собой ценностно-смысловое ядро национального позиционирования по отношению к окружающему миропространству. К изменчивым элементам можно отнести пластичные стереотипы, образующие “оболочку” ценностно-смыслового ядра менталитета и относящиеся к внешней форме внешнеполитического менталитета. Поскольку внешнеполитический менталитет эволюционирует очень медленно, едва ли возможно форсировать его изменение без риска вызвать нежелательные деструктивные сдвиги в общественном сознании [см. Южалина 2002: 60, 78].

Исследование периодов культурно-политических трансформаций восточных обществ, привнесших важные штрихи в самоидентификацию соответствующих наций, позволяет выявить амбивалентные тенденции. Заимствование западных ценностей, с одной стороны, приближает ту или иную страну к канонам западной политической культуры, а с другой - неизменно вызывает 
“отбойную волну”, запуская защитные механизмы консервации фундаментальных моральных норм, духовных ценностей и, главное, стиля мышления. В результате переделке подвергается, как правило, “фасад” общества, тогда как глубинные слои национального, в частности, внешнеполитического менталитета оказываются затронутыми в гораздо меньшей степени.

Высокий потенциал долготерпения, жертвенности, сопричастности к этнической общности, привязанности к иерархическим структурам в менталитете (например, японском) обеспечивает возможность довольно гармонично переживать кризис идентичности, адаптироваться к переменам, возникающие в результате ослабления социокультурной традиции под влиянием извне. В этом случае, как правило, деструкции ценностно-смыслового ядра менталитета не наблюдается, равно как и цепной реакции в виде аномии, ценностно-нормативного вакуума, разрыва в преемственности социальных и культурных норм и роста ретритизма.

Компаративный анализ различных периодов развития обществ позволяет выявить долгоживущие социокультурные константы и каузальную зависимость между экзогенными факторами и адаптивной реакцией на их воздействие. Если выполняется одно и то же условие, а именно, появляется угроза военной, экономической или информационной безопасности общества, то вне зависимости от других многообразных взаимодействий экономических, политических, социальных, культурных факторов воспроизводится один и тот же паттерн внутри- и внешнеполитических реакций: включаются специфические защитные механизмы, охраняющие ключевые национальные ценности. При этом адаптация к иным культурным ценностям может носить ритуальный характер, с явным присутствием элементов играизационных практик, приходящих в последнее время и во внешнюю политику, и в дипломатию.

\section{ИНФОРМАЦИОННАЯ СОСТАВЛЯЮЩАЯ ВНЕШНЕПОЛИТИЧЕСКОГО МЕНТАЛИТЕТА}

Менталитет, несомненно, имеет информационную природу, которая влияет на характер его коммуникационной функции. Изучая специфику менталитета, мы неизбежно сталкиваемся с проблемой накопления социальной информации, передачи негативного и позитивного опыта в массовом сознании, влияния накопленных сведений на переживаемую в данный момент действительность. Более того, взаимное восприятие народов и национально-этнических общностей формируется в их коммуникации. Давление информационных потоков на систему ценностей той или иной нации или этнической группы, а также социальных и культурных разрывов в виде интернационализации "чужих" ценностных систем воздействует на менталитет, обладающий, как уже отмечалось, существенной ригидностью в сравнении с общественным сознанием. Это давление производит амбивалентный эффект. С одной стороны (что давно изучено и многократно подтверждено), информация разрушает стереотипы и привносит новое знание. С другой стороны, сильное давление информационных потоков (информационный “прессинг”) обычно вызывает включение механизмов защиты от инородного влияния. Общественное сознание реагирует на избыточную информацию, обращаясь к тем же стереотипам, которые позволяют упростить картину происходящего во внешней политике. 
Отношение того или иного сообщества к окружающей внешней среде характеризуется информационной интерактивностью. В одних случаях внешняя среда воспринимается как “чужой мир", источник опасности, подчас вызывающий недоверие и подозрительность и, как следствие, неприятие и стремление дистанцироваться от него. В других - внешний мир интригует и притягивает к себе как источник новых идей, технологий, стандартов жизни, форм организации экономической и социальной сфер жизнедеятельности. Преобладание первого способа информационной интерактивности приводит к стойкой ксенофобии в обществе, тогда как доминирование второго - в максимальной степени благоприятствует заимствованию достижений других культур, хотя и чревато размыванием собственных ценностных оснований.

В координации этих двух поведенческих стратегий (отталкивание притяжение) ведущую роль играют информационные потоки. Явное доминирование любого из них приводит к неизбежной деформации внешнеполитического менталитета и самым негативным образом сказывается на политике государства. При скудной и спорадической информации картина внешнего мира искажается и обрастает домыслами, политическими мифами и этническими фобиями. Напротив, при наличии многообразной, доступной и адекватной информации складывается картина мира, в максимальной степени приближенная к реальности.

\section{НАЦИОНАЛЬНЫЙ ХАРАКТЕР И МЕНТАЛИТЕТ}

Менталитет нередко отождествляют с национальным характером. М.Мнацаканян обращает внимание на некоторую парадоксальность ситуации, которая заключается в следующем: “первоначальный смысл 'менталитета' и сегодня остается в разговорном обиходе, иногда в беллетристикепублицистике, а в науке он растворяется или в понятии 'культура', или в понятии 'национальный характер'. Налицо малопродуктивные попытки... привязать 'менталитет' в одном случае - только к культуре, в другом - к психологии” [Мнацаканян 2005: 203-204].

Понятия "внешнеполитический менталитет" и “национальный характер", действительно, очень близки, но не тождественны друг другу. Можно согласиться с мнением, что первое понятие по содержанию гораздо шире, чем второе. Отличие менталитета от национального характера состоит в том, что “последний, являясь составной частью ментальности, включает общие психофизиологические черты жизнедеятельности (определяемые принятой нацией системой ценностей)" [Моисеева, Сороковикова 2003: 46].

Национальный характер представляет собой сложную структурно-функциональную систему, ядром которой являются представления о типичных чертах определенной общности [Южалина 2002: 12]. Он тесно связан с менталитетом нации, включая его девиантные формы. Нарастание числа этнических, религиозных, социальных конфликтов оказывает деструктивное влияние на психику людей. В итоге формируется своего рода “патогенез” социума (его “искривление”, в частности, за счет патологии психического развития) и "нациопатия" (искажение национального характера во вред самой нации под воздействием бессознательного) [Попов 1997: 1]. Яркие 
примеры “нациопатии” - германский фашизм и крайняя форма национализма и мессианства в Японии 1930-х годов. В девиантном развитии менталитета нации стержневую роль играет национальная гордость, трансформируюшаяся в кичливость. В этом контексте примечательна максима А.Шопенгауэра: “Самый дешевый сорт гордости - это национальная гордость. Она обнаруживает, что одержимый ею страдает отсутствием индивидуальных качеств, которыми он мог бы гордиться... Национальному характеру, так как он свидетельствует о массе, по справедливости никогда нельзя приписать много хорошего. Напротив, человеческая ограниченность, извращенность и дрянность проявляются в каждой стране, только в другой форме, и это называется национальным характером” [Шопенгауэр 1991: 61].

Этнокультурный (этнический) менталитет, несомненно, является в высокой степени устойчивым типом менталитета. Его особая роль в структуре менталитета нации обусловлена этническими стереотипами, восходящими к архетипам. Эти этнические стереотипы суть долгоживущие константы национальной самобытности, обусловливающие ключевые черты этноса (особенности мировоззрения, характера, исторической судьбы, художественного творчества и т.д.) [Малькова 2004: 190]. Распространение этнических стереотипов, расширяя представления того или иного сообщества о "чужих" этносах, напрямую влияет на межэтнические и межгосударственные отношения.

\section{“МЫ"-ГРУППА И “ОНИ"-ГРУППА}

Понятия “Мы”-группа и “Они”-группа, введенные в научный оборот У.Самнером и изложенные им в монографии “Народные обычаи” в 1906 г., до сих пор не потеряли своей актуальности. Самосознание не дано нам априорно. Оно появляется в ходе построения своих отношений с “Другим”. Во всяком случае, как утверждает Т.Алексеева, “противопоставление своего/чужого, в сущности, носит субъективный характер и основывается на оценке, перцепции 'чужого'” [Алексеева 2007: 159]. У.Эко очень точно и образно охарактеризовал этот феномен: “Другой, взгляд Другого определяет и формирует нас... Мы... не способны осознать, кто мы такие, без взгляда и ответа Другого” [Эко 2003: 10]. Только через каналы коммуникации с "Другим" можно познать себя (также как мы не узнаем себя, пока не посмотрим в зеркало). Именно “Другой” (вернее, “значимый Другой”, “constituent other") выступает в роли зеркала. Мы самоутверждаемся благодаря признанию нашей индивидуальности другими. Более того, наша идентичность складывается из характеристик, которые дают другие.

Имманентную сопряженность ментальности и идентичности наиболее рельефно, на наш взгляд, выразил В.Попов: “'Менталитет” - это глубинные, вековые константы социального и национального характера, архетипические представления, ценности, идеалы жизни народа, а идентичность - соответствие, тождество...” [Попов 1997: 1]. Сознание человека, давая первичную оценку различным явлениям, относящимся к национальным атрибутам, немедленно разделяет их на знакомое (“свое”) и незнакомое (“чужое”), разбрасывая в противоположные стороны, подобно костяшкам на счетах. Первое обычно воспринимается позитивно, второе - зачастую 
враждебно. Соответственно, свои национальные ценности человек оценивает со знаком плюс, а все чужое, выходящее за круг привычного, становится ресурсом формирования антипатии.

Специфика национального характера, по мнению многих специалистов, находит выражение в иерархии образных представлений о "своем" (по контрасту с “чужим”), гранями которой являются образы “себя для других", “себя для себя" и “себя в себе”. Национальный образ “для себя" - это совокупность образных характеристик, осознаваемых и желательных в данном обществе. Здесь большое значение играют “своя" мифология, “своя” символика, имеющие хождение внутри этнической системы. Для сторонних наблюдателей заметны лишь их фрагментарные проявления. Национальный образ “для других” - это совокупность приписываемых себе характеристик, переведенная на язык других культур. Образ “для других” также расшифровывается через определенную символику, легенды и мифы, создаваемые с целью установить адекватную (с точки зрения образа “для себя") коммуникацию с внешним миром. Что касается национального образа "в себе", то эта иерархическая ступень выражает бессознательный опыт этноса. Однако именно от него зависит согласованность и ритмичность действий членов общности. Следовательно, национальный характер определяется бессознательным образом "в себе" и выражается через образы “для себя" и “для других”. Последние два образа связаны нитями интерактивности и корректируют друг друга [Южалина 2002: 12].

Адекватный образ своей национальной общности необходим для нормальной межэтнической коммуникации: если нация воспринимает внешний мир неадекватно, то создаются благоприятные условия для возникновения и развития межнациональных и межэтнических конфликтов. Чтобы сформировалось адекватное национальное самовосприятие, национальный менталитет должен быть включен в систему коммуникаций с окружающим миром, иначе внутреннее пространство навяжет нации бытие в себе. Бессмысленно постигать самого себя, если не сопоставляешь себя с внешней средой. “Для того чтобы видеть себя, внутреннее пространство должно стать частью внешнего пространства”, - отмечает японский исследователь К.Ямада [Yamada 1981: 194]. Если у страны не определена собственная идентичность, то у нее не может быть целостной внешней политики и полноценного международного сотрудничества.

\section{ВНЕШНЕПОЛИТИЧЕСКИЙ МЕНТАЛИТЕТ И НАЦИОНАЛЬНАЯ САМОИДЕНТИФИКАЦИЯ}

Внешнеполитический менталитет теснейшим образом связан с национальной самоидентификацией. Первый - важнейшая неотъемлемая часть второго и в большинстве контекстов два термина синонимичны. Самоидентификация* нации и национально-этнических групп определяется сознанием и переживанием ею своей целостности, сплоченности, а также своих интересов, своего места в социальном пространстве. Она прямо коррелирует с изменениями во внешнеполитическом менталитете. Это выра-

\footnotetext{
* Мы отдаем предпочтение термину “самоидентификация”, хотя в мировой научной литературе более прочно закрепился термин “идентичность".
} 
жается различном позиционировании себя по отношению к окружающим странам, к партнерам на региональном и глобальном уровнях, а также и в эволюции соответствующих дипломатических практик.

Проблема самоидентификации затрагивает ценности и символы. Термин "идентичность", используемый в западной литературе, наделяется разными смыслами. В Соединенных Штатах "политикой идентичности" ("politics of identity") называют курс этнических и других меньшинств, направленный на самоутверждение. В другом контексте термин “идентичность” употребляется по отношению к странам и группам, которые определяются относительно своей этнической, религиозной или национальной принадлежности [Cerutti, Rudloph (eds.) 2001: 2-3]. По мнению М.Тело и П.Манетта, изменение под влиянием глобализации “экономических и социальных систем, а также распространение новых информационных технологий способствуют формулированию новых требований к идентичности” [там же: 84]. В этом смысле глобализация и идентичность диалектически противопоставлены друг другу. Как уже упоминалось, унифицирующему воздействию универсалистских тенденций противостоят стойкие национальные (этнические) стереотипы, представляющие собой часть внешнеполитического менталитета и основу самоидентификации. В этом, возможно, и заключается одно из главных противоречий эпохи глобализации.

Особый круг исследователей (в основном географы) полагают, что картина мира и, главное, собственное место национально-этнической общности в этой картине осознаются через политико-географические образы стран или регионов [Замятин 1998: 80-92]. Примерно то же подразумевают исследователи, оперирующие понятием “геополитических кодов” - устойчивых внешнеполитических ориентаций, не зависящих от политической конъюнктуры в пределах длительного исторического периода. Утверждается, что геополитическое видение мира включает представления о территории этнической группы или политической нации, ее границах, предпочтительных или неприемлемых моделях государственного устройства, своей исторической миссии, внешних или внутренних силах, благоприятствующих или препятствующих ее осуществлению [Колосов 2002: 33-51]. На наш взгляд, применять категории географии и геополитики к феномену, описываемому в рамках внешнеполитического менталитета, излишне, так как это затеняет роль архетипических представлений, свойственных менталитету, вносит ненужную путаницу в систему социологических понятий. При нарастании избыточности в терминологии нелишне вспомнить принцип бритвы Оккама: “сущности не следует умножать без необходимости".

Некоторые исследователи трактуют внешнеполитический менталитет и самоидентификацию с помощью этнических (или национальных) стереотипов, в т.ч. и обращенных на самое себя. Суть самоидентификации постигается более полно при анализе терминологического поля ценностей и аттитюдов (т.е. норм отношения к нормам) [Diligenskij, Tchugrov 2000]. Но в данном контексте, если отойти от чисто терминологических отличий, речь идет об одном и том же. Главное - люди должны добровольно идентифицировать себя с ценностями и символами, определяющими идентич- 
ность. Позиционирование своей страны по отношению к другим странам, их ценностям и символам, и есть формирование внешнеполитического менталитета нации.

Вопрос самоидентификации встает особенно остро в ситуации, когда имеет место давление “чужих" ценностей. Если такое взаимодействие достигает интенсивности цивилизационного столкновения, то интенсивность и болезненность поиска собственной идентичности возрастает. В случае отторжения системой какой-либо “чужой” ценности, вступают в действие закономерности, которые для наглядности можно было бы обозначить термином "ксенотрансплантация" (изначально в медицине - отторжение инородной ткани). Институциональные и ценностные "трансплантанты” с чужой “группой крови” отторгаются политической системой. Однако есть нации, обладающие высокопластичным менталитетом и большими адаптационными способностями. Применительно к этим нациям критический порог “ксенотрансплантации” располагается существенно выше.

\section{ВНЕШНЕПОЛИТИЧЕСКИЙ МЕНТАЛИТЕТ И ВНЕШНЯЯ ПОЛИТИКА}

Изучение менталитета имеет сугубо практическое значение, что побуждает уделять особое внимание конативному аспекту проблемы. Перед исследователями внешнеполитического менталитета стоят практические задачи, связанные с управлением его изменениями. Как отмечает Б.Душков, менталитет в настоящее время становится “системообразующим фактором биогенетического и психологического развития, сознания и поведения людей, их совместной деятельности, общения, предметной деятельности и развития социальной активности народов (в том числе ноопсихологической и ноосоциологической активности и устойчивости)” [Душков 2002: 3-4].

На взаимозависимость внешнеполитического менталитета и внешнеполитического поведения (закрепившаяся англоязычная калька "foreign policy behavior”) влияют многие социально-политические и социально-экономические факторы. Среди них - территория, население, экономический потенциал, военная мощь, государственная стабильность, политический авантюризм, политические установки, имидж политических лидеров, методы политического воздействия, экономические экспектации, виды мотивационных предпочтений, социальная активность масс и др.

Внешнеполитическое поведение является для внешнеполитического менталитета продуктом предметной деятельности. Первое можно считать зависимой переменной от второго.

В заключение отметим, что вопрос о том, как интернационализация культурных систем воздействует на политическую составляюшую менталитета, имеет весьма важное эвристическое значение при анализе причин зарождения этнических конфликтов, изучении специфики восприятия окружающего мира и понимания преемственности этнонационального менталитета. Однако этот вопрос актуален не только в теоретическом плане. Он прямо влияет на характер принимаемых внешнеполитических решений, на отношения между народами. Исследование обществ в периоды изменения институтов, ценностей, норм и, конечно, самих людей (подчас эти процессы сопровождаются кризисом идентификаций) оказывается сегодня 
чрезвычайно актуальным. Раскрыть характер менталитета в эпоху трансформаций - значит, понять стержень изменений, а, следовательно, и вектор развития той или иной страны, перспективы взаимоотношений с ней.

Адорно Т. 2001. Исследование авторитарной личности. М.

Алексеева Т.А. 2007. Политическая философия. М.

Ануфриев Е.А., Лесная Л.В. 1997. Российский менталитет как социально-политический феномен. - Социально-политический журнал, № 4.

Ахиезер А.С. 1998. Россия: критика исторического опыта. Новосибирск.

Бергер П., Лукман Т. 1995. Социальное конструирование реальности. М.

Бердяев Н. 2004. Самопознание. М., Харьков.

Блок М. 1993. Апология истории. М.

Боткин Л.М. 1986. Два способа изучать историю культуры. - Вопросы философuu, № 2.

Бутенко А.П., Колесниченко Ю.В. 1996. Менталитет россиян и евразийство: их сущность и общественно-политический смысл. - Социс, № 5.

Вебер М. 1994. Избранное. Образ общества. М.

Вальцев С.В. 2004. Является ли понятие менталитет синонимом понятия ментальность? - Объединенный научный журнал, № 7.

Вятр Е. 1979. Социология политических отношений. М.

Горшков М.К. 2003. Российское общество в условиях трансформации (социологический анализ). М.

Грушин Б.А. 1987. Массовое сознание. М.

Губский Е. (ред.) 2002. Философский энциклопедический словарь. М.

Дилигенский Г.Г. 1998. Реформы и общественная психология. - Власть, № 5.

Дилигенский Г. 1999. Глобализация: перспективы демократии. - Полития, № 3.

Душков Б. 2002. Психосоциология менталитета и нооменталитета. М.

Дюркгейм Э. 2006. Социология. Ее предмет, метод, предназначение. М.

Егорова Е.В. 1988. США в межлународных кризисах. М.

Замятин Д.Н. 1998. Политико-географические образы и геополитические картины мира. - Полис, № 6.

Ильин И. 1993. О грядущей России. М.

Ключевский В.О. 1987. Сочинения в десяти томах. Т. 1. М.

Козловский В.В. 1997. Понятие ментальности в социологической перспективе. - Социология и социальная антропология. СПб.

Кола Д. 2001. Политическая социология. М.

Колосов В. 2002. "Низкая" и "высокая геополитика: образы зарубежных стран в представлениях российских граждан. - Общественные науки и современность, № 3.

Корнилов О. 2000. Языковые картины мира как отражения национальных менталитетов. Автореф. докт. культур. наук. М.

Кравченко А.И. 2000. Культурология: Словарь. М.

Кравченко С.А. (ред.). 1997. Учебный социологический словарь. М.

Кравченко С.А., Романов В.Л. 2004. Социология и вызовы современной социокультурной динамики. - Социс, № 4.

Лебедева М.М., Мельвиль А.Ю. 1999. "Переходный возраст” современного мира. - Международная жизнь, № 10.

Лебон Г. 1995. Психология народных масс. СПб.

Лосский Н.О. 2000. Ценность и Бытие: Бог и Царство Божие как основа ценностей. Харьков, М.

Малькова 2004. Этнические аспекты журналистики. М.

Маркс К. 2000. Социология: Сборник. М.

Манекин Р.В. 1991. Контент-анализ как метод исследования истории мысли. Клио, № 1.

Манхейм К. 1994. Диагноз нашего времени. М. 
Маркузе Г. 2003. Одномерный человек: исследование идеологии развитого индустриального общества. М.

Медведева С.М. 2006. Проблема политического стереотипа в зарубежннй политической психологии. М.

Ментальность, менталитет [б.г.]. - http://www.examen.ru/db/Examine/defacto.html

Михайлов Ф.Г. 1990. Общественное сознание и самосознание индивида. М.

Михайловский Н.К. 1998. Герои и толпа. - Михайловский Н.К. Избранные труды по социологии. В 2 т. Т. 2. СПб.

Мнацаканян М.О. 2005. Культуры. Этносы. Нации. М.

Моисеева Н.А., Сороковикова В.И. 2003. Менталитет и национальный характер. - Социс, № 2.

Мостовая И.В., Скорик А.П. 1995. Архетипы и ориентиры российской ментальности. - Полис, № 4.

Неклесса А. 2002. Внешняя политика нового мира: движение к нестационарной системе мировых связей. - Pro et Contra, № 4.

Новиков С. (ред.) 1998. Терра лексикон. М.

Панарин А.С. 2002. Глобальное политическое прогнозирование. М.

Попов В. 1997. Закон ментальной идентичности - НГ-Сценарии, № 9.

Пушкарев Л., Пушкарева Н. [б.г.] Ментальности (менталитет). - http://www.krugosvet.ru/articles/105/1010513/1010513a1.htm

Рогальская Н.П. 2006. Понятие "менталитет". - София, Вып. 9.

Сорокин П.А. 2006. Социальная и культурная динамика. М.

Степин В.С. 2000. Теоретическое знание. М.

Таршис Е.Я. 1999. Ментальность человека: подходы к концепции и постановка задач исследования. М.

Тощенко Ж.Т. 2003. Парадоксальный человек: феномен общественного сознания и исторической практики. - Время и человек в зеркале гуманитарных исследований. Курск.

Усенко О.Г. 1994. К определению понятия “менталитет”. - Русская история: проблемы менталитета. М.

Февр Л. 1991. Бои за историю. М.

Федотова В.Г. 1997. Модернизация “другой” Европы. М.

Фрейд 3. 1991. “Я” и “Оно”. Книги 1-2. Тбилиси.

Фромм Э. 2004. Анатомия человеческой деструктивности. М.

Хабермас Ю. 2003. Философский дискурс о модерне. М.

Чернышева Н.М. 2003. Включение понятия “ментальность” в категориальный аппарат социальных наук, философии и гуманитарного знания. - Российская ментальность: теоретические проблемы. М.

Шопенгауэр А. 1991. Афоризмы и максимы. Л.

Штомпка П. 1996. Социология социальных изменений. М.

Шюц А. 2004. Избранное: Мир, светящийся смыслом. М.

Эко У. 2003. Пять эссе на тему этики. СПб.

Южалина П.С. 2002. Менталитет, сущность и структура явления. Челябинск.

Cerutti R., Rudolph E. (eds.). 2001. A Soul for Europe. The Making of Europe. Vol. 1. Leuven.

Chaplin J.P. 1975. Dictionary of Psychology. NY.

Diligenskij G. Tchugrow. S. 2000. Der “Westen” im russischen Bewusstsein. Kцln.

Drever J. 1967. A Dictionary of Psychology. Hammondsworth.

Funk \& Wagnalis New Standart Dictionary of the English Language. 1962. NY.

The Universall Dictionary of English Language. 1957. L.

Yamada K. 1981. Ways of thinking in traditional philosophy; prospects and limits. Intellectual Creativity in Endogenous Culture. Tokyo.

Webster's Third New International Dictionary. 1961. L. 